\title{
DESAIN SISTEM PENGELOLAAN SAMPAH MELALUI PEMILAHAN SAMPAH ORGANIK DAN ANORGANIK BERDASARKAN PERSEPSI IBU - IBU RUMAH TANGGA
}

\author{
Sri Anastasia Yudistirani ${ }^{1}$, Lailan Syaufina ${ }^{2}$, Sri Mulatsih ${ }^{3}$ \\ ${ }^{1}$ Fakultas Teknik Universitas Muhammadiyah Jakarta \\ 2,3 Program Magister Pengelolaan Sumberdaya Alam dan Lingkungan, SPS-IPB \\ srianastasiayudistirani@yahoo.com
}

\begin{abstract}
ABSTRAK. Saat ini, volume sampah yang tinggi di Jakarta merupakan salah satu masalah penting bagi masyarakat Jakarta Timur. Berdasarkan data yang diperoleh dari Dinas Kebersihan Pemerintah Jakarta Timur, ada sekitar 30\% dari volume sampah yang tidak dikirim ke TPA per hari. Masalah ini berkaitan dengan kurangnya pendidikan tentang pentingnya pemisahan sampah oleh sebagian besar warga. Aturan pemerintah tentang pengelolaan sampah masih belum sepenuhnya dilaksanakan. Suatu lembaga konseling terpadu yang mengelola sampah untuk semua komponen di masyarakat diperlukan untuk memberikan hasil yang optimal. Sistem Pengelolaan Sampah harus melibatkan ibu-ibu rumah tangga dan harus menerapkan Pemerintah Peraturan Nomor 81 Tahun 2012 tentang tentang Pengelolaan Sampah Rumah Tangga dan jenis sampah rumah tangga yang lain. Penelitian ini menunjukkan bahwa dengan menggunakan sistem pemisahan pengelolaan sampah terpadu, volume sampah akan dturunkan sebesar 33\%. Penurunan ini disebabkan karena daur ulang sampah anorganik. Melalui cara ini, pemerintah Jakarta hanya perlu untuk mengelola sampah organik yang yang terdiri $67 \%$ dari semua limbah. Ini adalah suatu cara untuk mengurangi jumlah volume sampah di Jakarta
\end{abstract}

Kata Kunci : manajemen limbah, pemisahan, limbah organic, limbah anorganik

\section{PENDAHULUAN}

Sampah adalah material sisa dari aktivitas manusia yang tidak memiliki keterpakaian, karenanya harus dikelola. Tanpa pengelolaan secara baik dan benar, sampah dapat menimbulkan kerugian karena akan menyebabkan banjir, meningkatnya pemanasan iklim, menimbulkan bau busuk, mengganggu keindahan, memperburuk sanitasi lingkungan dan ancaman meningkatnya berbagai macam penyakit.

Pertumbuhan penduduk DKI yang meningkat $1.49 \%$ per tahun pada tahun 2011, dan perilaku hidup modern juga meningkatkan volume sampah yang dihasilkan oleh masyarakat DKI. Menurut data Dinas Kebersihan Jakarta Timur pada tahun 2012 setiap orang di
DKI menghasilkan $0.741 \mathrm{Kg}$ perhari (Suku Dinas Kebersihan Jakarta Timur, 2013)

Timbunan sampah di Jakarta Timur berasal dari 10 kecamatan, diantaranya masih terdapat sampah yang tidak terangkat setiap hari dari 7 kecamatan yaitu: (Kecamatan Matraman 16.76 Ton/hr, Jatinegara 14.53 Ton/hr, Pasar Rebo 59.06 Ton/hr, Cakung 207.7 Ton/hr, Duren Sawit 137.98 Ton/hr, Ciracas 31.46 Ton/hr, Cipayung 77.27 Ton/hr) (Suku Dinas Kebersihan Jakarta Timur, 2011). Sampah yang menumpuk jika dikelola akan menjadi berkah, sebaliknya jika tidak dikelola dapat menimbulkan masalah.

Gambar 1 menunjukkan komposisi sampah anorganik di DKI Jakarta 
mencapai 33\%. Jika dipilah sejak awal, maka volume sampah anorganik yang komposisinya mencapai 33\% ini dapat diambil langsung dari sumbernya (yaitu rumah tangga) oleh penggiat daur ulang.

Sistem pengelolaan sampah melalui pemilahan juga tertuang dalam Peraturan Pemerintah Nomor 81 Tahun 2012 tentang Pengelolaan Sampah Rumah Tangga dan Sampah Sejenis Sampah Rumah Tangga. Pada pasal 17 (1) disebutkan bahwa pemilahan dilakukan oleh setiap orang pada sumbernya.
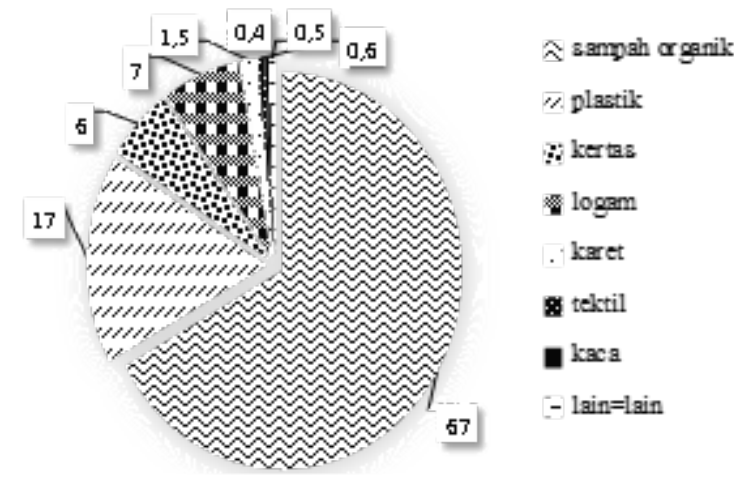

Sumber:

Dinas Kebersihan DKI Jakarta, 2013

Gambar 1. Komposisi Sampah di DKI Jakarta 2013

\section{Rumusan Masalah}

Pemilahan sampah oleh masyarakat masih belum banyak dilakukan. Padahal peran serta masyarakat dalam mengurangi volume sampah dengan cara memilah sampah dari sumber asalnya sangat penting. Rumah tangga merupakan salah satu sumber asal sampah terbesar di DKI Jakarta sebesar $78 \%$. Oleh karena itu, peran rumah tangga dalam pemilahan sampah merupakan ujung tombak dalam pengelolaan sampah secara keseluruhan. Untuk mengkaji sejauh mana peran rumah tangga dalam pemilahan sampah, maka beberapa pertanyaan perlu dijawab sebagai berikut:

1. Bagaimana partisipasi ibu - ibu rumah tangga dalam memilah sampah
2. Faktor-faktor apa saja yang mempengaruhi perilaku ibu - ibu rumah tangga untuk memilah sampah.

3. Bagaimana desain sistem pengelolaan sampah anorganik untuk meningkatkan partisipasi masyarakat dalam memilah sampah.

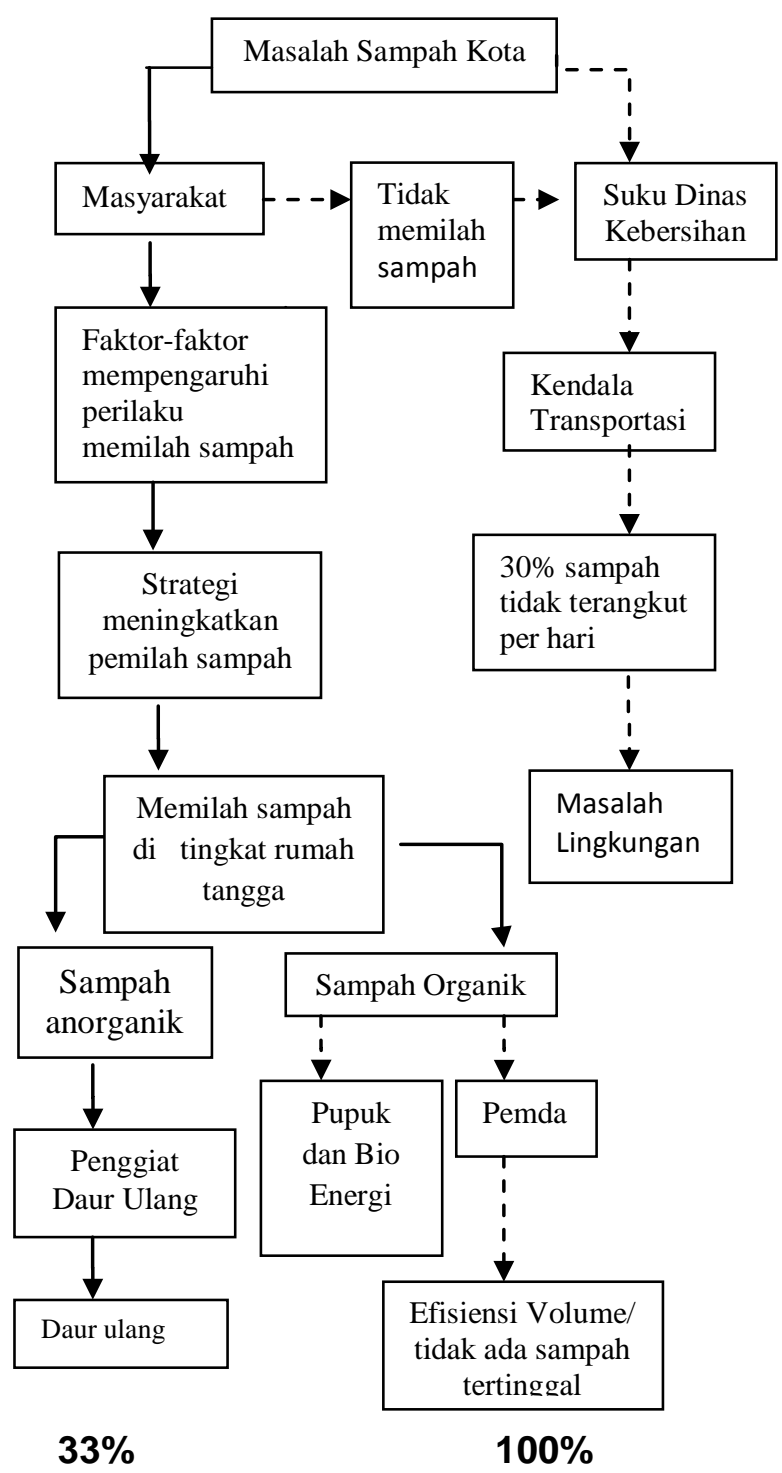

Gambar 2. Kerangka Pemikiran Penelitian

\section{Tujuan Penelitian}

1. Mengukur partisipasi ibu - ibu rumah tangga dalam memilah sampah

2. Menganalisis persepsi dan faktorfaktor yang mempengaruhi pemilah sampah oleh ibu - ibu rumah tangga. 
3. Membuat design sistem pengelolaan sampah anorganik untuk meningkatkan partisipasi masyarakat dalam memilah sampah melalui faktor pengendali.

\section{Manfaat Penelitian}

Hasil penelitian ini diharapkan dapat digunakan untuk memberi masukan kepada pemerintah daerah dalam mengatasi masalah timbunan sampah yang tertinggal melalui partisipasi masyarakat dalam memilah sampah rumah tangga.

\section{TINJAUAN PUSTAKA}

Pengelolaan Sampah Kota Jakarta Secara teoritik, untuk mengatasi persoalan sampah mengharuskan dilakukannya pergeseran pendekatan dari pendekatan ujung-pipa (end-pipe of solution) ke pendekatan sumber. Dengan pendekatan sumber, maka sampah ditangani ada pada hulu sebelum sampah itu sampai ke tempat pengolahan akhir (hilir) (Putro 2002).

Dinas Kebersihan DKI Jakarta selama ini menggunakan 2 cara pengumpulan sampah sebagai berikut (Dinas Kebersihan DKI Jakarta, 2011):

a. Sistem door to door, pengumpulan dilakukan oleh petugas dengan mendatangi tiap-tiap rumah tangga kemudian dikumpulkan di tempat penampungan sementara.

b. Sistem Komunal, pengumpulan dilakukan sendiri oleh masingmasing rumah tangga ke tempat yang sudah disediakan.

Kapasitas maksimum penampungan TPST dan TPA dengan batasan:

a. TPST Sunter daya tampung 1200 ton/hari dapat menampung sampah yang berasal dari wilayah Jakarta Timur sebesar $1200 \times 26.5 \%=318$ ton/hari

b. TPST PDUK Cacing (CakungCilincing) dengan kapasitas daya tampung maksimum 1300 ton/hari dan dapat menampung sampah yang berasal dari wilayah Jakarta
Timur sebesar $1300 \times 26.5 \%=344$ ton/hari

c. TPA Bantar Gebang dengan kapasitas daya tampung maksimum 5200 ton/hari dan dapat menampung sampah yang berasal dari wilayah Jakarta Timur $5200 \times 26.5 \%=1378$ ton/hari

Dari kapasitas maksimum ke 3 TPA tersebut dapat diketahui kemampuan daya tampung TPA dan dapat dihitung berapa banyak sampah yang akan tertinggal seiring bertambahnya waktu dan bertambahnya penduduk.

\section{Teori Persepsi \\ Pengertian Persepsi}

Persepsi adalah proses bagaimana seseorang menyeleksi, mengatur, dan menginterpretasikan masukanmasukan informasi untuk menciptakan gambaran keseluruhan yang berarti. Persepsi dapat diartikan sebagai suatu proses kategorisasi dan interpretasi yang bersifat selektif (Kotler 1993). Selain itu juga persepsi ini tidak bertahan seumur hidup dapat berubah sesuai dengan perkembangan pengalaman, perubahan kebutuhan, dan sikap dari seseorang baik laki-laki maupun perempuan.

Faktor yang Mempengaruhi Persepsi
Ivancevich dan Donelly
mengemukakan bahwa persepsi
membantu individu dalam
mengatur, memilih,
menginterpretasikan menyimpan dan
menjadi gambaran dunia yang utuh dan
berarti. Di antara karakteristik pribadi
yang lebih relevan yang mempengaruhi
persepsi adalah sikap, motif,
kepentingan atau minat, pengalaman
masa lalu, dan pengharapan
(ekspektasi).


Faktor Eksternal

- Pengetahuan \& Informasi

- Keadaan / Lingkungan

- Keadaan Sosial \& Ekonomi

- Latar Belakang

- Penerapan Kebijakan
Faktor Internal: o Sikap o Motivasi o Kepentingan o Pengalaman o Pengharapan

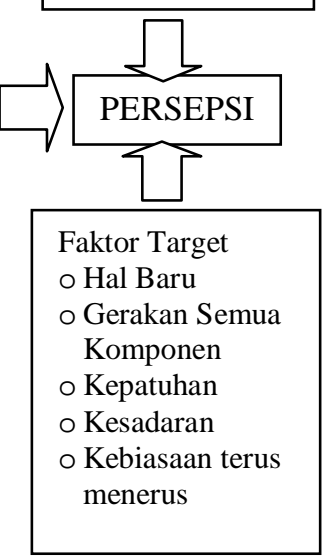

Gambar 3. Faktor yang mempengaruhi Persepsi

\section{METODE PENELITIAN}

\section{Lokasi dan Waktu Penelitian}

Penelitian ini menggunakan data primer dan data sekunder. Data primer diambil dari wawancara dengan ibu-ibu rumah tangga sebagai responden dan Data sekunder diambil dari data Suku Dinas Kebersihan DKI Jakarta serta hasil penelitian sebelumnya. Sampel ibu-ibu diambil secara purposif dengan jumlah 102 responden, yang terdiri dari 64 orang di Kecamatan Duren Sawit, Jakarta Timur dan 38 orang dari Kecamatan Bogor Utara. Alasan pengambilan dua kecamatan tersebut adalah untuk mewakili wilayah yang belum mendapatkan penyuluhan pemilahan sampah (Jakarta Timur) dan yang sudah mendapatkannya (Bogor).

\section{Jenis dan Sumber Data}

Data yang digunakan dalam penelitian ini merupakan data primer dan data sekunder. Data primer berupa informasi tentang persepsi ibu-ibu rumah tangga yang memilah sampah dan yang bukan memilah sampah dikumpulkan melalui wawancara dengan ibu - ibu rumah tangga langsung di lapangan. Data sekunder diperoleh melalui studi pustaka, dan instansi-instansi pemerintah yang terkait dengan penelitian.

\section{Metode Analisis Regresi logit}

Metode regresi logistic untuk mengukur partisipasi masyarakat dalam memilah sampah, persamaan regresi logistic berdasarkan Pendekatan fungsi logit digunakan untuk mengetahui faktorfaktor yang mempengaruhi pemilahan sampah oleh masyarakat.

$$
\begin{aligned}
& \text { Logit (pi) }=\quad \beta_{0}+\beta_{1} X_{1}+\beta_{2} X_{2}+ \\
& \ldots+\beta_{7} X_{7}+\varepsilon \\
& \text { pi } \quad \text { : peluang ruman....(2) }
\end{aligned}
$$

memilah sampah

$\mathrm{X}_{\mathrm{i}-\mathrm{n}} \quad$ : peubah penjelas ke $\mathrm{i}-\mathrm{n}$

BO : konstanta intersep model garis regresi

$\beta 1_{1-n} \quad$ : koefisien peubah penjelas ke 1-n

$\varepsilon \quad$ : error term

Dalam menentukan faktor - faktor penentu pemilah digunakan 7 peubah penjelas atau peubah bebas, yaitu:

$\mathrm{X}_{1}=$ Pendidikan terakhir $(0=$ SMA, $1=$ $\mathrm{S} 1$ dan $2=\mathrm{S} 2)$

$X_{2}=\operatorname{Umur}(0<30$ th, $1=$ antara $30-50$ th, dan $2=>50$ th)

$X_{3}=$ Lama tinggal $(0=<5$ th, $1=$ antara $5-20$ th, $2=>20$ th)

$\mathrm{X}_{4}=$ Jenis Pekerjaan $(0=$ ibu rumah tangga, 1 = PNS, dan 2 = swasta)

$X_{5}=$ Jumlah anggota keluarga $(0=4$ orang, $1=$ antara $4-10$ orang, dan $2=>10$ orang)

$\mathrm{X}_{6}=$ Pendapatan $(0=<5$ juta, $1=$ antara 5 juta -20 juta, $2=>20$ juta)

$\mathrm{X}_{7}=$ Penyuluhan $(0=$ belum ada penyuluhan, dan 1 = sudah ada penyuluhan)

\section{Metode deskriptif}

Metode deskriptif digunakan untuk menyajikan alasan melakukan dan tidak melakukan pemilahan sampah serta membuat desain sistem pemilahan sampah anorganik. 


\section{HASIL DAN PEMBAHASAN}

Partisipasi ibu rumah tangga dalam pemilahan sampah

Model Logit yang digunakan dalam penelitian ini bersifat binary yaitu memilah sampah (nilai 1) dan belum memilah sampah (nilai 0). Hasil analisis stepwise didapat hasil tiga faktor yang berpengaruh yaitu dua faktor intrinsik ditambah satu faktor ekstrinsik seperti pada Tabel 1.

Tabel 1. Hasil analisis statistik faktorfaktor penentu pemilahan sampah

\begin{tabular}{|c|c|c|c|c|c|}
\hline Peubah & df & B & Wald & $\begin{array}{c}\text { Odd } \\
\text { Ratio / } \\
\text { Exp(B) } \\
\end{array}$ & $\begin{array}{c}P \\
\text { Hitung }\end{array}$ \\
\hline Pendidikan & 2 & & 5.528 & & $0.063 *$ \\
\hline $\begin{array}{l}\text { Pendidikan(1 } \\
\text { ) }\end{array}$ & 1 & 1.327 & 5.528 & 3.770 & $0.019 * *$ \\
\hline Pendidikan(2 & 1 & 21.005 & 0.000 & 0.000 & 0.999 \\
\hline Umur & 2 & & 4.743 & & 0.093 \\
\hline Umur(1) & 1 & 2.015 & 4.150 & 0.133 & $0.042 * *$ \\
\hline Umur(2) & 1 & $\begin{array}{c}- \\
1.098\end{array}$ & 1.226 & 0.333 & 0.268 \\
\hline $\begin{array}{l}\text { Penyuluhan( } \\
\text { 1) }\end{array}$ & 1 & 2.496 & 17.115 & 0.082 & $\begin{array}{l}0.000^{* *} \\
*\end{array}$ \\
\hline Constant & 1 & 1.739 & 3.353 & 5.693 & 0.067 \\
\hline $\begin{array}{l}\text { Chi Square (df } \\
=\end{array}$ & 7) & & 40.939 & & \\
\hline Probabilitas & & & 0.000 & & \\
\hline $\begin{array}{l}\text { Nagelkerke } \\
\text { R } \\
\text { Count R }\end{array}$ & square & & 0.453 & & \\
\hline $\begin{array}{l}\text { square } \\
\text { (percentage } \\
\text { Correct) }\end{array}$ & & & 77.5 & & \\
\hline
\end{tabular}

***sangat nyata pada taraf $u j i<1 \%, * \star$ nyata pada taraf uji $<5 \%$, *cenderung nyata pada taraf uji $<10 \%$

Berdasarkan hasil analisis regresi logistik dengan uji stepwise maka diketahui bahwa dari tiga faktor yang mempunyai pengaruh signifikan terhadap status memilah sampah (pemilah dan bukan pemilah) yaitu pendidikan, umur dan penyuluhan. Model logit yang terbentuk adalah sebagai berikut.

$$
\begin{aligned}
\operatorname{Logit}\left(\mathrm{p}_{\mathrm{i}}\right)= & 1.739+ \\
& 1.327^{\star} \text { Pendidikan(1) - } \\
& 21.005^{\star} \text { Pendidikan(2) - } \\
& 2.015^{\star} \text { Umur(1) - }
\end{aligned}
$$

\subsection{8*Umur(2) - \\ 2.496*Penyuluhan(1)}

Dari ketiga faktor yang memberikan kontribusi terhadap model tercatat nilai nagelkerke $R$ square adalah 0.453 yang berarti pendidikan, umur dan penyuluhan mampu menjelaskan $45.3 \%$ faktor pemilah dan bukan pemilah, ini berarti bahwa ketiga faktor tesebut dalam uji stepwise menjadi faktor yang sangat penting dalam membedakan status pemilah dan bukan pemilah, adapun sisanya $54.7 \%$ dijelaskan oleh faktor lain yang tidak masuk dalam model penelitian.

\section{Pendidikan}

Faktor pendidikan responden cenderung nyata pada taraf $10 \%$. Responden dengan pendidikan S1 mempunyai peluang memilah sampah 3.770 kali lebih besar dari responden dengan pendidikan SMA. Adapun responden dengan pendidikan S2 belum melakukan pemilahan sampah dengan ditunjukan dengan nilai odd rasio 0.000 atau peluang untuk memilah sampah sama dengan nol. Semakin tinggi pendidikan maka semakin tinggi pemahaman terhadap pentingnya lingkungan yang bersih, dan mengetahui bahwa sampah perlu dikelola lebih baik. Perilaku unik ini dikarenakan mereka sibuk dengan pekerjaannya dan tidak mau direpotkan untuk memilah sampah. pendidikan S2 yang masuk dalam penelitian ini yaitu berjumlah 2 orang setelah dikonfirmasi melalui penelitian kualitatif berdasarkan wawancara dengan responden mereka menyatakan bahwa sangat sibuk.

\section{Umur}

Dari faktor umur terlihat bahwa responden dengan umur 30 tahun hingga 50 tahun mempunyai pengaruh nyata pada model dengan nilai $P$ hitung 0.042 kurang dari 5\% dan nilai Odd rasio 0.133 yang berarti bahwa responden yang memilah sampah dibawah 30 tahun ada $41.7 \%$ dari 12 orang yang berumur dibawah 30 tahun. 
Sedangkan responden yang memilah sampah dengan usia diatas 50 tahun sebesar $38.1 \%$ atau 8 orang dari 21 orang responden berusia diatas 50 tahun. Jika dihubungkan dengan waktu luang usia responden dibawah 30 tahun yang adalah ibu rumah tangga masih memiliki keluarga kecil dengan beban waktu luang lebih besar dari responden dengan usia antara 30 hingga 50 tahun, begitu juga untuk responden dengan usia diatas 50 tahun untuk mayoritas ibu rumah tangga dengan waktu luang yang lebih besar dibanding usia antara 30 hingga 50 tahun ini tentunya kesempatan untuk menjadi pemilah sampah lebih besar.

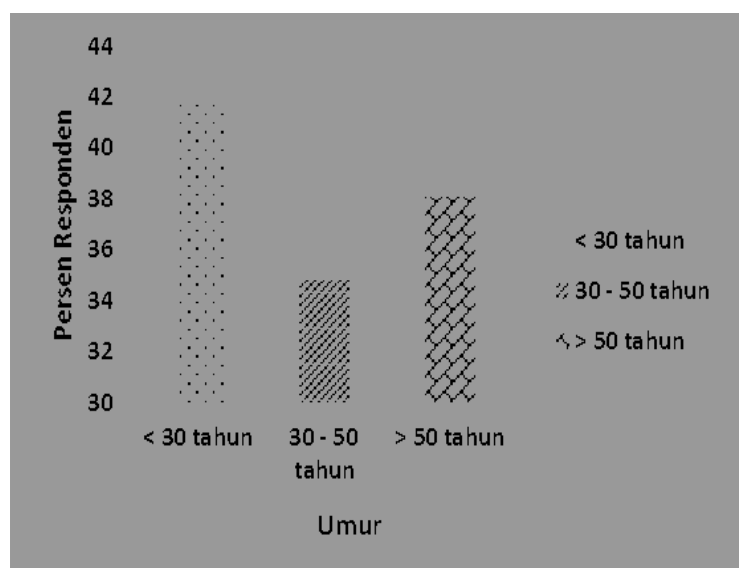

Gambar 4 . Pemilah berdasarkan Kelompok Umur

Adapun umur diatas 50 tahun nampaknya tidak berbeda nyata dengan umur dibawah 30 tahun dalam status memilah sampah seperti terlihat pada tabel 2 .

Tabel 2. Pemilah berdasarkan Kelompok Umur

\begin{tabular}{|c|c|c|c|c|c|}
\hline \multirow{3}{*}{ Umur (tahun) } & \multicolumn{4}{|c|}{ Status Pemilah } & \multirow{3}{*}{$\begin{array}{c}\text { Total } \\
\text { (Orang) }\end{array}$} \\
\hline & \multicolumn{2}{|c|}{ Pemilah } & \multicolumn{2}{|c|}{ bukan pemilah } & \\
\hline & Orang & $\%$ & Orang & $\%$ & \\
\hline$<30$ & 5 & 41.7 & 7 & 58.3 & 12 \\
\hline $30-50$ & 24 & 34.8 & 45 & 65.2 & 69 \\
\hline \multirow[t]{2}{*}{$>50$} & 8 & 38.1 & 13 & 61.9 & 21 \\
\hline & 37 & 36.3 & 65 & 63.7 & 102 \\
\hline
\end{tabular}

\section{Penyuluhan}

Responden yang belum mendapatkan penyuluhan memiliki 0.082 kali lebih rendah untuk memilah sampah dibanding responden yang sudah diberikan penyuluhan ini mengindikasikan bahwa penyuluhan sampah menjadi sangat penting mendorong responden dalam melakukan pemilahan sampah

Tabel 3. Status pemilah berdasarkan
daerah penelitian
dann

\section{Analisa persepsi dan faktor-faktor yang mempengaruhi pemilah sampah}

Metode yang digunakan adalah Analisa Deskriptif untuk melihat persepsi ibu ibu rumah tangga yang memilah dan tidak memilah dikarenakan faktor Penyuluhan, Jarak ke tempat sampah, Peraturan, Kebijakan, Jenis sampah yang dihasilkan dan faktor kebiasaan. Serta menghitung persepsi jika ibu ibu rumah tangga yang belum memilah sampah setelah diberikan stimulus berupa fasilitas dan peraturan untuk bersedia jadi pemilah sampah.

Tabel 4. Persepsi responden dalam pelibatan penggiat

Daur ulang dalam pemilahan sampah

\begin{tabular}{lcc}
\hline Persepsi & \multicolumn{3}{c}{ Jumlah responden } & $\%$ \\
\hline Setuju & 96 & 94.1 \\
Tidak setuju & 6 & 5.9 \\
\hline Total & 102 & 100.0 \\
\hline
\end{tabular}

Persentase Pemilah Sampah

Dari total 102 responden, sebanyak $63.7 \%$ belum memilah sampah rumah tangga. Responden yang berasal Bogor sebagian besar (65.8\%) sudah memilah sampah. Sebaliknya, responden yang berasal dari Jakarta sebagaian besar belum memilah sampah yaitu sebesar $81.2 \%$.

Pelibatan pihak Swasta Dalam Pengelolaan Sampah Anorganik Dari 102 responden, sebagian besar (94.1\%) menyatakan setuju perlunya 
melibatkan pendaur ulang dalam mengelola sampah anorganik .

\section{Pengaruh Pemilah yang berasal dari Penyuluhan}

Tabel 5. Peran penyuluhan dalam pemilahan sampah

\begin{tabular}{cllllll}
\hline Status & \multicolumn{4}{c}{$\begin{array}{l}\text { Pemilah } \\
\text { Orang } \\
\text { \% }\end{array}$} & \multicolumn{3}{c}{$\begin{array}{l}\text { Bukan } \\
\text { Pemilah } \\
\text { Orang }\end{array}$} \\
\hline Bogor & $\begin{array}{l}\text { Ada } \\
\text { penyuluhan }\end{array}$ & 25 & 5.8 & 13 & 34.2 \\
Jakarta & $\begin{array}{l}\text { Tidak ada } \\
\text { penyuluhan }\end{array}$ & 12 & 8.8 & 52 & 81.2 \\
\hline Total & 102 & 37 & 3.1 & 65 & 56.9 \\
\hline
\end{tabular}

Tabel 5 menunjukan bahwa responden yang sudah mendapatkan penyuluhan sebagian besar (65.8\%) bersedia menjadi pemilah sampah sedangkan $34.2 \%$ responden menyatakan belum bersedia. Responden yang belum mendapatkan penyuluhan, sebagian besar belum bersedia memilah sampah (81.2\%), hanya sebagian kecil (18.8\%) yang bersedia memilah sampah. Responden yang sudah diberikan penyuluhan tetapi belum bersedia memilah memberikan beberapa alasan antara lain bahwa mereka memang sudah terbiasa memberikan botol plastik kepada pemulung dan mereka beranggapan sudah cukup dengan memilah sebatas pada botol plastik, walaupun mereka sadar manfaat yang didapat dari memilah terhadap kualitas lingkungan hidupnya. Dengan demikian, penyuluhan dapat mempengaruhi responden untuk memilah sampah.

\section{Analisa persepsi dan faktor-faktor yang mempengaruhi pemilah sampah oleh ibu - ibu rumah tangga.}

Metode yang digunakan adalah Analisa Deskriptif untuk melihat persepsi ibu ibu rumah tangga yang memilah dan tidak memilah dikarenakan faktor Penyuluhan, Jarak ke tempat sampah, Peraturan, Kebijakan, Jenis sampah yang dihasilkan dan faktor kebiasaan. Serta menghitung persepsi jika ibu -ibu rumah tangga yang belum memilah sampah diberikan stimulus berupa fasilitas dan peraturan untuk bersedia jadi pemilah sampah.

\section{Prosentase Pemilah Sampah}

Secara keseluruhan dari 102 responden terlihat bahwa sebagian besar mencapai $63.7 \%$ adalah mereka yang belum memilah sampah rumah tangga. Untuk responden yang berasal Bogor dari 38 responden yang berpartisipasi dalam survei tercatat sebagian besar sudah memilah sampah yaitu mencapai $65.8 \%$ sebaliknya responden dari jakarta dengan jumlah partisipasi dalam survei mencapai 64 responden nampaknya sebagai besar belum memilah sampah yaitu sebesar $81.2 \%$.

Tabel 6. Status pemilah berdasarkan daerah penelitian

\begin{tabular}{|c|c|c|c|c|}
\hline \multirow[b]{2}{*}{$\begin{array}{l}\text { lokasi } \\
\text { penelitian }\end{array}$} & \multicolumn{3}{|c|}{ Status Pemilah } & \multirow[b]{2}{*}{ Total } \\
\hline & $\begin{array}{l}\text { Pemilah } \\
\text { Orang \% }\end{array}$ & & $\begin{array}{l}\text { an } \\
\text { ilah } \\
\text { ng \% }\end{array}$ & \\
\hline Bogor & 2565.8 & 13 & 34.2 & 38 \\
\hline Jakarta & 1218.8 & 52 & 81.2 & 64 \\
\hline Total & 36.3 & 65 & 63.7 & 102 \\
\hline
\end{tabular}

Alasan responden telah memilah sampah adalah lebih dominan karena mereka ingin membantu melestarikan lingkungan yaitu tercatat sebanyak 30 orang dari 37 orang pemilah sampah (81\%) sedangkan sisanya 7 orang atau $19 \%$ responden beralasan bermanfaat untuk diri sendiri. Berdasarkan interview kualitatif peneliti dengan responden mereka sangat memahami bahwa masalah sampah dapat menimbulkan kerusakan lingkungan yang berujung penurunan kualitas kesehatan, tetapi mereka berharap semua komponen masyarakat dapat melakukannya serentak dan bersamaan sehingga tercapai lingkungan bersih yang signifikan. 
Tabel 7. Alasan Responden Memilah Sampah

\begin{tabular}{lrc}
\hline Alasan memilah sampah & $\begin{array}{c}\text { Jumlah } \\
\text { Orang }\end{array}$ & $\begin{array}{c}\text { responden } \\
\%\end{array}$ \\
\hline $\begin{array}{l}\text { Bermanfaat untuk diri } \\
\text { sendiri. }\end{array}$ & 7 & 19 \\
$\begin{array}{l}\text { Membantu pelestarian } \\
\text { lingkungan. }\end{array}$ & 30 & 81 \\
\hline Total & 37 & 100 \\
\hline
\end{tabular}

Alasan tidak memilah sampah adalah lebih karena memilah sampah itu merepotkan mencapai $87 \%$ atau sebanyak 57 orang dari 65 orang yang bukan pemilah sampah. Selanjutnya tercatat $13 \%$ responden belum memilah sampah dikarenakan bahwa memilah sampah tidak bermanfaat, tidak memiliki 2 jenis tempat sampah atau tidak terbiasa. Hal ini menyita waktu mereka, dan banyak juga dari mereka karena tidak terbiasa menjadi sering lupa, banyak tetangga juga belum peduli.

Tabel 8. Alasan Responden Tidak memilah sampah

\begin{tabular}{|c|c|c|}
\hline \multirow{2}{*}{$\begin{array}{l}\text { Alasan tidak memilah } \\
\text { sampah }\end{array}$} & \multicolumn{2}{|c|}{ Jumlah responden } \\
\hline & Orang & $\%$ \\
\hline Merepotkan & 57 & 87 \\
\hline Tidak bermanfaat & 2 & 3 \\
\hline Alasan & \multicolumn{2}{|c|}{$\begin{array}{l}\text { Jumlah } \\
\text { responden }\end{array}$} \\
\hline Memiliki nilai ekonomis & & 2 \\
\hline Total & & 2 \\
\hline $\begin{array}{l}\text { Tidak memiliki } 2 \text { jenis } \\
\text { tempat sampah }\end{array}$ & 3 & 5 \\
\hline Tidak terbiasa & 3 & 5 \\
\hline Total & 65 & 100 \\
\hline
\end{tabular}

Pelibatan pihak Swasta Dalam Pengelolaan Sampah Anorganik

Dari 102 responden terlihat bahwa sebagian besar responden mencapai 99 orang (94.1\%) menyatakan setuju perlunya melibatkan pendaur ulang dalam mengelola sampah anorganik dan sisanya 2 orang menyatakan tidak setuju
Tabel 9. Pelibatan dengan penggiat daur ulang

\begin{tabular}{lr}
\hline Alasan & Jumlah responden \\
\hline Ya setuju & 96 \\
Tidak setuju & 6 \\
\hline Total & 102 \\
\hline
\end{tabular}

Responden yang menyatakan setuju perlunya keterlibatan dengan penggiat daur ulang yaitu sebanyak 99 orang dari 102 orang adalah lebi karena alasan dianggap beramal yaitu mencapai 57,6\%. Sedangkan yang memiliki alasan adanya kompensasi dan karena karena adanya peraturan masing - masing 21 orang atau 21,2\% responden.

Tabel 10.Alasan setuju

\begin{tabular}{lcr}
\hline Alasan & \multicolumn{2}{r}{$\begin{array}{r}\text { Jumlah } \\
\text { responden }\end{array}$} \\
\hline & Orang & $\%$ \\
\hline Dianggap beramal. & 57 & 57.5 \\
Ada kompensasi. & 21 & 21.2 \\
lkut karena ada & 21 & 21.2 \\
peraturan. & & \\
\hline Total & 99 & 100 \\
\hline
\end{tabular}

Adapun dua orang yang menyatakan tidak setuju perlunya melibatkan penggiat daur ulang adalah lebih karena alas an bahwa sampah anorganik memiliki nilai ekonomis sehingga tidak perlu keterlibatan penggiat daur ulang. Kedua orang tersebut selama ini telah mengelola bank sampah.

Tabel 11. Alasan Tidak Setuju

\section{Pengaruh Pemilah yang berasal dari Penyuluhan}

Untuk daerah penelitian Bogor Utara te;ah dilakukan peneyuluhan pemilahan sampah dimana tercatat 25 responden $(65.8 \%)$ bersedia menjadi pemilah sampah sedangkan 13 orang lainnya menyatakan belum bersedia. Sedangkan untuk wilayah jakarta responden belum pernah memperoleh penyuluhan. Dari responden jakarta ternyata 12 orang sudah memilah sampah (18.8\%) sedangkan sisanya 52 
lainnya yang tinggal di jakarta belum memilah sampah. Responden yang sudah diberikan penyuluhan namum belum bersedia memilah memberikan alasan antara lain bahwa mereka memang sudah terbiasa memberikan botol plastik kepada pemulung dan mereka beranggapan sudah cukup dengan memilah sebatas pada botol plastik, ada juga responden yang beranggapan bahwa kompensasi ditawarkan tidak sebanding dengan repotnya memilah, walaupun mereka sadar manfaat yang didapat dari memilah terhadap kualitas lingkungan hidupnya. Dari tabel 9 terlihat bahwa penyuluhan dapat memberikan pengaruh nyata terhadap responden untuk bersedia memilah sampah setelah diberikan secara serentak dilokasi tersebut.

Tabel 12. Pengaruh penyuluhan

\begin{tabular}{lllll}
\hline Status & & \multicolumn{2}{l}{$\begin{array}{l}\text { Pemilah } \\
\text { Orang \% }\end{array}$} & \multicolumn{2}{l}{$\begin{array}{l}\text { Bukan } \\
\text { Pemilah } \\
\text { Orang }\end{array}$} \\
\hline Bogor & $\begin{array}{l}\text { Ada } \\
\text { penyuluhan }\end{array}$ & $\begin{array}{l}25 \\
65.8\end{array}$ & \multicolumn{1}{c}{13} & 34.2 \\
Jakarta & $\begin{array}{l}\text { Tidak ada } \\
\text { penyuluhan }\end{array}$ & 12 & 52 & 81.2 \\
& 18.8 & & \\
\hline Total & 102 & 37 & 65 & 56.9 \\
& & 43.1 & & \\
\hline
\end{tabular}

Penyuluhan yang diberikan 100\% dilakukan oleh pihak pengurus RT untuk wilayah penelitian di Bogor Utara.

Tabel 13. Pemberi Penyuluhan

\begin{tabular}{lr}
\hline Alasan & $\begin{array}{r}\text { Jumlah } \\
\text { responden }\end{array}$ \\
\hline Pengurus RT & 38 \\
Penyuluh Dinas Kebersihan & - \\
Institusi & - \\
pendidikan/LSM/perorangan & 38 \\
\hline Total & \\
\hline
\end{tabular}

\section{Pengaruh terhadap Jarak Tempat Pembuangan Sampah}

Sebagian besar responden memilih jarak lebih dari 20 meter untuk letak tempat pembuangan sampah sementara dari rumah atau sebesar $50 \%$ dari jumlah responden, sedangkan 47 orang responden memilih jarak pembuangan $10 \mathrm{~m}-20 \mathrm{~m}$ atau sebesar $46.1 \%$ dari rumah dan 4 orang lainnya memilih jarak kurang dari $10 \mathrm{~m}$ tempat pembuangan sampah dari rumahnya.

Tabel 14.Terhadap Jarak

Pembuangan Sampah

\begin{tabular}{lr}
\hline Jarak & Jumlah responden \\
\hline$>20 m$ dari rumah & 51 \\
$10-20 \mathrm{~m}$ dari & 47 \\
rumah & 4 \\
$<10 \mathrm{~m}$ dari rumah & 102 \\
\hline Total & \\
\hline
\end{tabular}

\section{Pengaruh Terhadap Sampah yang dihasilkan}

Sebagian besar responden lebih dominan menghasilkan sampah anorganik mencapai 53,9\% sedangkan $38,2 \%$ menghasilkan jenis sampah yang sama dan 7,8 \% menghasilkan sampah lebuh banyak sampah organik, dari data ini dapat disimpulkan ,jika rata - rata responden menghasilkan volume sampah sama besar maka didaerah ini volume sampah anorganik dapat dipastikan lebih besar dari sampah organik. Pemilah maupun bukan pemilah lebih dominan jenis sampah anorganik kemudian campuran (anorganik dan organik)

Tabel 15. Jenis Sampah

\begin{tabular}{lr}
\hline Alasan & Jumlah responden \\
\hline Anorganik & 55 \\
Organik & 8 \\
Sama banyak & 39 \\
\hline Total & 102 \\
\hline
\end{tabular}

\section{Pengaruh Terhadap peraturan pemilahan sampah}

Sebagian besar responden $74.5 \%$ belum pernah mengetahui kewajiban mmnnmemilah sampah Bagi pemilah atau bukan pemilah nampaknya mempunyai kecenderungan yang sama bahwa mereka sebagian besar belum mengetahui peraturan memilah sampah 
Tabel 16. Pengaruh mendengar peraturan pemilahan

\begin{tabular}{|c|c|c|c|c|}
\hline \multicolumn{4}{|c|}{ Peraturan memilah sampah } & \multirow[t]{2}{*}{ Total } \\
\hline & & Pernah & $\begin{array}{l}\text { Belum } \\
\text { Pernah }\end{array}$ & \\
\hline \multirow[t]{2}{*}{ Status } & Pemilah & 14 & 23 & 37 \\
\hline & $\begin{array}{l}\text { Bukan } \\
\text { Pemilah }\end{array}$ & 12 & 53 & 65 \\
\hline
\end{tabular}

\section{Tingkat Persepsi setelah diberi fasilitas}

Meskipun demikian terlihat bahwa responden yang belum memilah nampaknya bersedia untuk memilah asalkan diberikan fasilitas. Terlihat $90.8 \%$ bersedia memilah sampah

Tabel 17. Pengaruh dari ketersediaan 2 jenis tempat sampah

\begin{tabular}{lr}
\hline Alasan & Jumlah responden \\
\hline Bersedia & 59 \\
Tidak bersedia & 6 \\
\hline Total & 102 \\
\hline
\end{tabular}

Alasan bersedia memilah lebih dominan karena membantu program kebersihan mencapai $75 \%$ responden yang bukan pemilah

Tabel 18. Pengaruh dari alasan bukan pemilah

\begin{tabular}{lr}
\hline Alasan & Jumlah responden \\
\hline $\begin{array}{l}\text { Membantu program } \\
\text { kebersihan }\end{array}$ & 45 \\
Bermanfaat & 12 \\
lkut karena ada & 3 \\
peraturannya & \\
\hline Total & 60 \\
\hline
\end{tabular}

Responden yang bukan pemilah sampah tidak bersedia karena alasan tidak terbiasa. Bukan pemilah 5 orang tetap tidak bersedia memilah sampah walaupun sudah diberi fasilitas

Tabel 19. Alasan tidak bersedia

\begin{tabular}{lr}
\hline Alasan & Jumlah responden \\
\hline merepotkan & 1 \\
Tidak terbiasa & 4 \\
\hline Total & 5 \\
\hline
\end{tabular}

Sumber informasi bagi pemilah untuk memilah sampah lebih didominasi karena faktor orang lain yang mencapai $92.3 \%$ atau 24 responden dari 26 responden yang memilah.

Tabel 20. Sumber informasi pemilah

\begin{tabular}{lr}
\hline Alasan & Jumlah responden \\
\hline Televisi & 2 \\
Radio & 0 \\
Majalah/buku & 0 \\
Orang lain (keluarga, & 24 \\
kerabat dan lainnya) & \\
\hline Total & 26 \\
\hline
\end{tabular}

Sebanyak $73 \%$ responden menyatakan bahwa faktor ekonomi juga dominan memutuskan memilah sampah dari 26 responden pemilah sampah yang bersedia memberikan persepsi pengaruh dari faktor ekonomi.

Tabel 21. Faktor eknomi sehingga memilah sampah

\begin{tabular}{lr}
\hline Alasan & Jumlah responden \\
\hline Ya & 19 \\
Tidak & 7 \\
\hline Total & 26 \\
\hline
\end{tabular}

Kebiasaan memilah sampah juga karena ada kebiasaan ditempat tinggal $71.9 \%$ atau 23 orang, dan 5 orang menyatakan bahwa adat dari keluarga yang mempengaruhi kebiasaan memilah, serta 4 orang lainnya dipengaruhi dari kebiasaan orang tua.

Tabel 22. Kebiasaan memilah

\begin{tabular}{lr}
\hline Alasan & Jumlah responden \\
\hline Orang Tua & 4 \\
Adat keluarga & 5 \\
Adat di tempat & 23 \\
tinggal & \\
\hline Total & 32 \\
\hline
\end{tabular}

Dorongan dari lingkungan tempat tinggal bagi pemilah untuk memilah sampah mencapai $80 \%$ dari responden pemilah sampah

Tabel 23. Dorongan dari lingkungan pemilah

\begin{tabular}{lr}
\hline Alasan & Jumlah responden \\
\hline Ya & 24 \\
Tidak & 6 \\
\hline Total & 30 \\
\hline
\end{tabular}


Tabel 24. Faktor - faktor ekstrinsik peubah pemilah sampah

\begin{tabular}{|c|c|c|c|}
\hline \multicolumn{2}{|c|}{ Faktor Penentu Peubah } & \multirow{2}{*}{$\begin{array}{l}\text { Pemilah } \\
\text { Orang } \\
\% \\
12 \\
32.4\end{array}$} & \multirow{2}{*}{$\begin{array}{l}\text { Bukan } \\
\text { Pemilah } \\
\text { Orang } \\
\% \\
39 \\
60.0\end{array}$} \\
\hline \multirow{3}{*}{$\begin{array}{l}\text { Jarak } \\
\text { Pembuangan } \\
\text { Sampah dari } \\
\text { rumah }\end{array}$} & $>20 \mathrm{~m}$ & & \\
\hline & $10-20 \mathrm{~m}$ & $\begin{array}{l}25 \\
67.6 \\
\end{array}$ & $\begin{array}{l}22 \\
33.8 \\
\end{array}$ \\
\hline & $<10 m$ & $0^{0}$ & $\begin{array}{c}4 \\
6.2\end{array}$ \\
\hline \multirow{2}{*}{$\begin{array}{l}\text { Keberadaan } \\
\text { kebijakan } \\
\text { ditempat } \\
\text { tinggal } \\
\text { responden }\end{array}$} & $\begin{array}{l}\text { Ada } \\
\text { (Bogor) }\end{array}$ & 25 & 12 \\
\hline & $\begin{array}{l}\text { Belum } \\
\text { (Jakarta) }\end{array}$ & 13 & 52 \\
\hline \multirow{2}{*}{$\begin{array}{l}\text { Bersedia } \\
\text { memilah } \\
\text { untuk } \\
\text { menerapkan } \\
\text { peraturan }\end{array}$} & Bersedia & - & 63 \\
\hline & $\begin{array}{l}\text { Tidak } \\
\text { Bersedia }\end{array}$ & - & 2 \\
\hline \multirow[t]{3}{*}{$\begin{array}{l}\text { Alasan } \\
\text { Bersedia } \\
\text { memilah }\end{array}$} & $\begin{array}{l}\text { Siap } \\
\text { membantu } \\
\text { program } \\
\text { kebersihan }\end{array}$ & - & 46 \\
\hline & Bermanfaat & - & 11 \\
\hline & $\begin{array}{l}\text { Ikut karna } \\
\text { ada } \\
\text { peraturan }\end{array}$ & - & 4 \\
\hline \multirow{2}{*}{$\begin{array}{l}\text { Melibatkan } \\
\text { Penggiat } \\
\text { Daur Ulang }\end{array}$} & Setuju & 36 & 1 \\
\hline & $\begin{array}{l}\text { Tidak } \\
\text { setuju }\end{array}$ & 60 & 5 \\
\hline \multirow{2}{*}{$\begin{array}{l}\text { Dorongan } \\
\text { dari } \\
\text { Lingkungan } \\
\text { Pemilah }\end{array}$} & $\mathrm{Ya}$ & 26 & - \\
\hline & Tidak & 4 & - \\
\hline \multirow{2}{*}{$\begin{array}{l}\text { Faktor } \\
\text { Ekonomi }\end{array}$} & $\mathrm{Ya}$ & 17 & - \\
\hline & Tidak & 7 & - \\
\hline \multirow{4}{*}{$\begin{array}{l}\text { Alasan Tidak } \\
\text { Bersedia } \\
\text { Memilah }\end{array}$} & Merepotkan & - & 57 \\
\hline & $\begin{array}{l}\text { Tidak } \\
\text { Bermanfaat }\end{array}$ & - & 2 \\
\hline & $\begin{array}{l}\text { Tidak } \\
\text { Memiliki } \\
\text { tempat } \\
\text { sampah }\end{array}$ & - & 3 \\
\hline & $\begin{array}{l}\text { Tidak } \\
\text { Terbiasa }\end{array}$ & - & 3 \\
\hline
\end{tabular}

Deskripsi tabel 24. Faktor - faktor penting peubah pemilah sampah:

a. Ternyata dilingkungan tempat tinggal yang telah menerapkan kebijakan dalam hal ini lokasi penelitan di Bogor masih terdapat $24,3 \%$ atau 12 warganya masih belum memilah sampah, tetapi untuk lokasi penelitian di Jakarta yang belum terdapat kebijakan lokal yang menyarankan warganya untuk memilah terdapat 13 warga sudah melakukan pemilahan. b. Sedangkan bila terdapat penerapan peraturan terlihat 63 orang yang bersedia memilah sampah dari total 65 responden yang berstatus bukan pemilah sampah, sedangkan 2 orang tetap menyatakan tidak bersedia untuk menjadi pemilah sampah.

c. ternyata baik responden dengan status pemilah maupun responden dengan status bukan pemilah sama - sama setuju bahwa pengelolaan sampah anorganik melibatkan pihak penggiat daur ulang.

d. ternyata baik responden dengan status pemilah maupun responden dengan status bukan pemilah, mayoritas beralasan bahwa mereka siap membantu program kebersihan ada 46 responden, dan 11 responden beralasan bermanfaat serta sisanya 4 responden mengatakan bersedia mengikuti karena ada peraturannya.

e. ternyata responden dengan status pemilah sebanyak 26 orang dari 30 responden yang menjawab pertanyaan, menyatakan bahwa faktor lingkungan pemilah menjadi salah satu penentu melakukan pemilahan sampah.

f. ternyata responden dengan status pemilah sebanyak 17 orang dari 24 orang yang menjawab pertanyaan menyatakan faktor ekonomi menjadi salah satu penentu dalam menentukan pemilahan sampah.

g. Responden dengan status bukan pemilah memiliki alasan yang paling dominan, dengan alasan merepotkan sebanyak 57 responden dari 65 responden bukan pemilah sampah dan alasan lain seperti tidak bermanfaat dan tidak memiliki 2 tempat sampah terpisah serta alasan tidak terbiasa masing-masing 2 dan 3 orang responden. Ini mengindikasikan bahwa alasan merepotkan berpengaruh nyata untuk menjadi faktor penting bagi responden 
dalam memutuskan tidak /memilah sampah.

\section{Desain Sistem Pegelolaan Sampah Tingkat lbu - ibu rumah tangga}

Dalam periode 2011 - 2013, pertumbuhan sampah di DKI Jakarta mengalami peningkatan sebesar 39.15 per hari (Tabel 25.). Adanya perubahan penanganan sampah di Wilayah Jakarta Timur dengan melibatkan pihak Swasta yang semula hanya ditangani oleh Pemda DKI Jakarta, ternyata masih terdapat timbunan sampah yang tertinggal, dan tentunya dengan pembiayaan yang tidak sedikit.

Berdasarkan kajian tentang persepsi ibu-ibu rumah tangga dalam pemilahan sampah dan pentingnya pemilahan sampah dari sumber asalnya, usulan desain sistem pengelolaan sampah tingkat rumah tangga dapat dilihat pada Gambar 5.

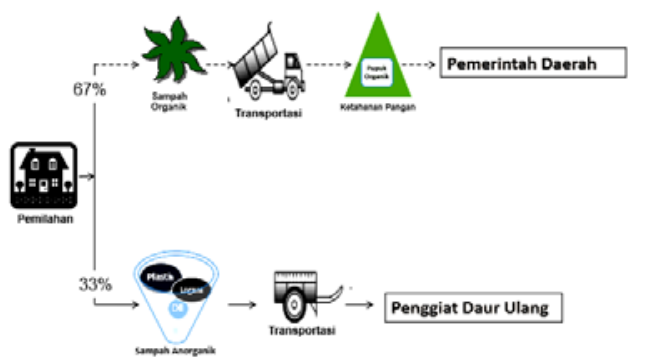

Gambar 5. Deskripsi Desain Sistem Pengelolaan Sampah tingkat Rumah Tangga

Penjelasan:

1. Pemilahan sampah berawal dari rumah tangga masing-masing, dengan memisahkan sampah organik dan sampah anorganik pada tempatnya masing-masing, bisa dengan tempat sampah yang biasa digunakan selama ini, hanya perlu diberikan label jenis sampah sehingga seluruh anggota keluarga dapat turut serta.

Tabel 25. Timbunan Sampah di Wilayah Jakarta Timur tahun 2011 dan tahun 2013

\begin{tabular}{|c|c|c|c|c|c|c|c|}
\hline $\begin{array}{l}\text { Wilayah } \\
\text { Kecamatan }\end{array}$ & $\begin{array}{l}\text { Timbunan } \\
\text { sampah } \\
2011 \\
\text { (Ton/hari) }\end{array}$ & $\begin{array}{l}\text { Timbunan } \\
\text { sampah } \\
2013 \\
\text { (Ton/hari) }\end{array}$ & $\begin{array}{l}\text { Terangkat } \\
\text { (Ton/hari) } \\
2011 \\
\text { Dinas }\end{array}$ & $\begin{array}{l}\text { Terangkat } \\
\text { (Ton/hari) } \\
2013 \\
\text { Dinas+Swasta }\end{array}$ & $\begin{array}{l}\text { Tidak } \\
\text { Terangkat } \\
\text { (Ton/hari) } \\
2011\end{array}$ & $\begin{array}{l}\text { Tidak } \\
\text { Terangkat } \\
\text { (Ton/hari) } \\
2013\end{array}$ & $\begin{array}{l}\text { Pertumbuhan } \\
\text { Sampah } \\
\text { periode } \\
2011 \text { - } 2013\end{array}$ \\
\hline Matraman & 98 & 126 & 81.24 & $54+75.20-3.2$ & 16.76 & - & 22.22 \\
\hline Jatinegara & 177.6 & 205.74 & 163.07 & $81+89.85$ & 14.53 & 34.38 & 13.68 \\
\hline Pulogadung & 172.2 & 179.86 & 172.2 & $58.5+199.41-78.05$ & - & - & 4.26 \\
\hline Kramat Jati & 179.5 & 182.44 & 179.5 & $67.5+165.69-50.75$ & - & - & 1.61 \\
\hline Pasar Rebo & 123.7 & 131.74 & 64.64 & $67.5+21.58$ & 59.06 & 42.66 & 6.10 \\
\hline Cakung & 332 & 340.87 & 124.3 & $103.5+82.29$ & 207.7 & 155.08 & 2.60 \\
\hline Duren Sawit & 252 & 251.13 & 114.02 & $90+57.71$ & 137.98 & 103.42 & -0.35 \\
\hline Makasar & 124.4 & 133.95 & 124.4 & $58.5+23.89$ & - & 51.56 & 7.13 \\
\hline Ciracas & 166.8 & 138.22 & 135.34 & $58.5+69.12$ & 31.46 & 10.6 & -20.68 \\
\hline Cipayung & 150.8 & 154.80 & 73.53 & $54+27.10$ & 77.27 & 73.7 & 2.58 \\
\hline
\end{tabular}

Sumber: diolah dari data Suku Dinas Kebersihan Jakarta Timur, 2011 dan 2013

2. Setelah sampah terpilah, dapat dibuang ditempat pembuangan sampah sementara yang juga sudah terpisah antara tempat pembuangan sampah organik dan tempat pembuangan sampah anorganik, untuk memudahkan masyarakat tempat sampah ini dapat dibedakan warnanya serta diberi label.
3. Alat transportasi dari tempat pembuangan sementara ke tempat pembuangan sampah akhir juga dapat dibedakan warna serta diberi label

4. Pemerintah daerah dapat mengelola sampah yang hanya sampah organik saja, sedangkan sampah anorganik pengelolaannya dilakukan oleh penggiat daur ulang sampah, hal ini dapat dimulai dari tempat 
pembuangan sementara dimana penggiat daur ulang bertanggung jawab penuh mulai dari transportasi awalnya dengan menggunakan kesepakatan bersama antara Pemda DKI dan Penggiat Daur Ulang.

5. Pengelolaan sampah organik juga dapat melibatkan pihak swasta yang bergerak di bidang penyediaan pupuk dan pertanian.

\section{KESIMPULAN DAN SARAN}

\section{Kesimpulan}

1. Partisipasi responden dalam pemilahan sampah di wilayah Bogor (65.8\%) dan wilayah Jakarta (18.8\%)

2. Faktor pendidikan, umur dan penyuluhan berpengaruh nyata pada keputusan memilah sampah. Penerapan PP No. 81 tahun 2012 tentang pemilahan sampah dari sumbernya oleh pemerintah setempat akan mendorong rumah tangga untuk melakukan pemilahan sampah.

3. Desain pengelolaan sampah dengan pembagian tugas sebagai berikut: rumah tangga sebagai pemilah sampah organik dan anorganik, penggiat daur ulang sebagai pengelola sampah anorganik, dan pemerintah daerah mengelola sampah organik.

\section{Saran:}

1. Pemerintah Daerah harus menerapkan peraturan PP. No.81 Tahun 2012 yang mewajibkan setiap warganya untuk melakukan pemilahan sampah dari sumbernya serta menerapkan sangsi bagi yang tidak bersedia memilah sampah harus mengelola sampahnya sendiri dengan membuang sampah ditempat sendiri

2. Pemerintah harus menggiatkan penyuluhan berjenjang dari Walikota sampai ke tingkat ketua rukun tetangga, sehingga tujuan pemilahan dapat disosialisasikan dengan baik sampai ke ibu - ibu rumah tangga, dan harus memperbaiki sistem yang sudah ada dengan cara menyediakan bak sampah dan truk dengan warna yang berbeda untuk masing-masing jenis sampah. Pemerintah Daerah melalui Dinas Kebersihan yang melibatkan aparatur kecamatan/ Kelurahan agar memantau proses pemilahan sampah yang dilakukan oleh Ibu-Ibu rumah tangga secara periodik/ berkala.

3. Pemerintah dapat bekerjasama dengan penggiat daur ulang (swasta) untuk mengelola sampah anorganik sehingga volume sampah yang ditangani pemerintah hanya sampah organik dengan demikian dapat mengatasi volume sampah anorganik yang besarnya mencapai $30 \%$.

\section{DAFTAR PUSTAKA}

Abidin Z., 1995. Hubungan Tingkat Partisipasi Ibu Rumah Tangga Dengan Perilaku Manajemen Sampah Dalam Program Solo Berseri di Kecamatan Serengan, Surakarta. Universitas Gajah Mada

Adiprigandari SA, 2011. Pengembangan Manajemen Bank Sampah guna Meningkatkan Kesejahteraan Masyarakat dan Kelestarian Lingkungan, Universitas Indonesia

Agung, IGN, 2014. Manajemen Penyajian Analisis Data Sederhana, Penerbit PT Rajagrafindo Persada

Asrul HI, Yulita V., Usman, 2012. Pengembangan Model Manajemen Distribusi Sampah Perkotaan, Universitas Pancasila

Friman L., Sahwan FS, 2010. Kualitas Produk Kompos Karakteristik Proses Pengomposan Sampah Kota Tanpa Pemilahan Awal, Jurnal Teknologi Lingkungan Vol. 11 No. 1, Jakarta

Sampah Rumah Tangga Yang 
dibuat Dengan Menggunakan Menggunakan "Komposter" Aerobik, Jurnal Teknologi Lingkungan Vol 12 no 3, Jakarta

David D., Syafrinaldi, Aci LTM., Ferdian NP. 2006. Pilot Project Peningkatan Kesadaran Masyarakat Dalam Pengelolaan Sampah Rumah Tangga Dengan Cara Pemilahan di Kota Padang. Universitas Andalas.Padang

Kotler, P. 1995. Marketing Management Analysis, Planning, Implementation \& Control. Prentice Hall Int.

Lisye F., Suprayogi, Susi S., Julianti P., 2008. Manajemen Pengelolaan
Sampah di Kota Bandung, Institut Teknologi Nasional

Putro R.FX S., 2002. Manajemen Pelayanan Sampah Perkotaan, Universitas Gajah Mada

Wahono S., Friman L. Sahwan FS, 2013. Pengelolaan Sampah Berbasis Masyarakat di Rawasari, Kelurahan Cempaka Putih Tengah, Jurnal Teknologi Lingkungan Vol. 10 No. 1, Jakarta Gibson, Ivancevich, Donnelly. 1997. Organisasi, Perilaku, Struktur, Proses. Jilid 1. Jakarta, Binarupa Aksara 